\title{
Eight hundred years of environmental changes in a high Alpine lake (Gossenköllesee, Tyrol) inferred from sediment records
}

\author{
Christian KAMENIK ${ }^{1)^{*}}$, Karin A. KOINIG ${ }^{2,3)}$, Roland SCHMIDT ${ }^{1)}$, Peter G. APPLEBY ${ }^{4)}$, John A. DEARING ${ }^{5)}$, \\ Andrea LAMI $^{6}$, Roy THOMPSON ${ }^{7}$, Roland PSENNER ${ }^{2)}$ \\ ${ }^{1)}$ Austrian Academy of Science, Institute of Limnology, Gaisberg 116, 5310 Mondsee, Austria \\ ${ }^{2}$ University of Innsbruck, Department of Zoology and Limnology, Technikerstr. 25, 6020 Innsbruck, Austria \\ ${ }^{3)}$ Present Address: Institute of Geology, University of Bern, Balzerstr. 1, CH-3012 Bern, Switzerland \\ ${ }^{4)}$ University of Liverpool, Department of Mathematical Sciences, Liverpool L69 3BX, United Kingdom \\ ${ }^{5)}$ University of Liverpool, Department of Geography, Liverpool L69 3BX, United Kingdom \\ ${ }^{6}$ C.N.R., Istituto Italiano di Idrobiologia, Largo Tonolli 50, Pallanza I-28048, Italy \\ ${ }^{7)}$ University of Edinburgh, Department of Geology and Geophysics, Grant Institute, West Mains Road, Edinburgh EH 93 JW, UK \\ *e-mail corresponding author: christian.kamenik@oeaw.ac.at
}

\begin{abstract}
Documentary and sediment records (diatoms, chrysophyte stomatocysts, plant pigments, carbon and nitrogen, metals and mineral magnetics) were used to reconstruct environmental changes in the high alpine lake Gossenköllesee (Tyrol, Austria) during the last 800 years. The records revealed complex interactions between human impact and climate. Gossenköllesee was predominantly influenced by land-use, which supplied nutrients to the lake. Documentary records report intensive sheep and cattle farming in the area around Gossenköllesee during medieval times. Pigments and chrysophyte stomatocysts indicated high nutrient concentrations prior to ca 1770 AD. First changes in land-use, however, were already detected ca 1670 AD. In 1675 AD the "Schwaighof" near Gossenköllesee, a perennial high altitude settlement, was sold to the Earl of Spaur, and farm management probably changed. After approx. $1770 \mathrm{AD}$ in-lake production was reduced, indicating a decrease in land-use. According to historical records, the perennial settlement near Gossenköllesee was abandoned by at least 1890 AD. Gossenköllesee was also affected by fish stocking. Arctic charr (Salmo trutta morpha fario L.) was introduced into the lake, most probably at the end of the $15^{\text {th }}$ century. A decline in carbon, nitrogen and the pigments alloxanthin (cryptophytes) and astaxanthin (grazers) indicate a significant removal of grazers by fish. Superimposed on human activity, climate changes have also had a significant impact on Gossenköllesee. High productivity during the $12^{\text {th }}$ century suggested by the plant pigment records might have been favoured by temperature increases, indicated by pronounced glacier retreats which began during the $10^{\text {th }} / 11^{\text {th }}$ century. The "Schwaighof" near Gossenköllesee was sold to the Earl of Spaur when winter temperatures declined substantially in the 1670s. Changes in C/N ratio, iron, manganese and mineral magnetics indicated increased detrital input from the catchment, starting approx. $1670 \mathrm{AD}$. Erosion and detrital input into the lake intensified during cold periods (1688-1701 AD and 1820-1850 AD), as indicated by a high C/N ratio, metals and mineral magnetics.
\end{abstract}

Key words: palaeolimnology, multi-proxy approach, land-use, climate, erosion, alpine lakes

\section{INTRODUCTION}

Anthropogenic and climatic changes have significantly influenced high alpine lakes over many centuries. Meadows and pastures above the timberline have been used for cattle breeding since neolithic times. During the Bronze Age irrigation and increased deforestation reflected intensified cattle farming, culminating in perennial high altitude settlements during medieval times. The pronounced influence of long-term human impacts is best documented by the present timberline, which is located below its natural level in large parts of the Alps (Patzelt et al. 1997; Wick \& Tinner 1997).

Climate fluctuations recorded by pronounced glacier advances and retreats have also significantly influenced alpine ecosystems (Patzelt 1973; Grabherr et al. 1994; Wick \& Tinner 1997). Remote alpine lakes are sensitive indicators of these changes (Psenner \& Schmidt 1992; Schmidt \& Psenner 1992; Sommaruga-Wögrath et al. 1997; Koinig et al. 1998) and palaeolimnological rec??ords in these lakes are one of the most important sources of information about long term changes. As many proxies as possible are used to gain as much information as possible, to provide a better understanding of the complex interactions in these ecosystems. Gossenköllesee (Tyrol, Austria) was selected for interdisciplinary palaeolimnological studies within the MOLAR (MOuntain LAkes Research) project. Documentary and sediment records (diatoms, chrysophyte stomatocysts, plant pigments, carbon and nitrogen, metals and mineral magnetics) from these studies are presented here and used to reconstruct the environmental history of the lake during the past 800 years.

\section{SITE LOCATION}

Gossenköllesee is located in Kühtai, Central Alps (47 $13^{\prime} 46^{\prime}$ 'N, $11^{\circ} 00^{\prime} 51^{\prime}$ 'E), situated above the present timberline (2417 $\mathrm{m}$ a.s.1.; Fig. 1). Boulders dominate the bed of the lake. Only areas below approx. $9 \mathrm{~m}$ water 


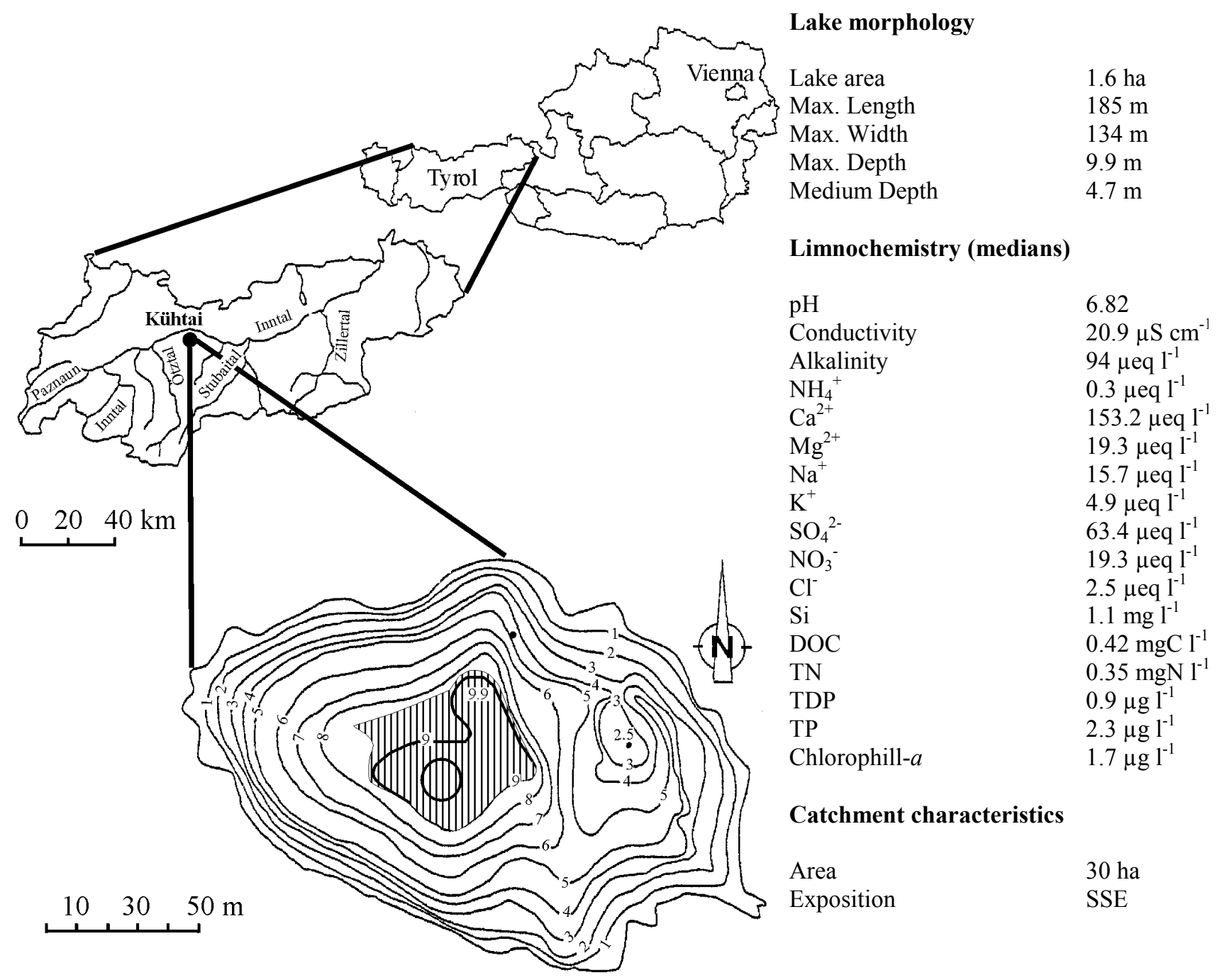

Fig. 1. Geographical position, bathymetric map and characteristics of Gossenköllesee. The shaded area indicates soft sediment. The circle illustrates the coring position of all cores presented in this paper.

depth consist of soft sediments (Zaderer 1982; Fig. 1). The catchment consists of granite, gneiss and amphibolite. Only $10 \%$ of the catchment is covered with soil and vegetation (alpine grass, heather; Heisberger 1988). In summer, these areas are used for sheep farming. The lake has diffuse, temporary in- and outflows. It is only moderately sensitive to acidification (Wögrath 1995). Lake characteristics are summarised in figure 1.

\section{MATERIAL AND METHODS}

Four cores were taken from the deepest part of the lake (Fig. 1), using a Kajak corer, and sub-sampled immediately after coring. For details of the coring, subsampling and analyses performed on each core see table 1.

\subsection{Chronology and core correlation}

Core GKS2 was dated by ${ }^{210} \mathrm{~Pb},{ }^{226} \mathrm{Ra}$, and ${ }^{137} \mathrm{Cs}$. Measurements of these radionuclides were carried out by direct gamma assay, using Ortec HPGe GWL series well-type coaxial low background intrinsic germanium detectors (Appleby et al. 1986; Appleby et al. 1992). The ${ }^{210} \mathrm{~Pb}$ chronology was calculated using the CRS dating model (Appleby \& Oldfield 1978) and its validity assessed using the methods described in Appleby \& Oldfield (1983), Appleby et al. (1991), Appleby (1993), Appleby (1998).

Dates of cores GKS3 and GKS5 were estimated either by correlation with GKS2 using a sequence slotting procedure based on the LOI (loss-on-ignition) data (Thompson \& Clark 1989), or, in the case of GKS95, by applying an average accumulation rate, derived from cores GKS1, GKS2, GKS4 and GKS5 (Koinig et al. 
Tab. 1. Details on coring, sub-sampling and analyses performed on each core.

\begin{tabular}{lcccc}
\hline Core code & Coring date & Length & Sampling interval & Whole core analyses \\
\hline GKS95 & $19^{\text {th }}$ April 1995 & $34 \mathrm{~cm}$ & $0.25 \mathrm{~cm}(<20 \mathrm{~cm}) 0.5 \mathrm{~cm}(>20 \mathrm{~cm})$ & Diatoms, chrysophyte stomatocysts \\
GKS2 & $18^{\text {th }}$ July 1996 & $30 \mathrm{~cm}$ & $0.25 \mathrm{~cm}$ & WW, DW, LOI, dating, magnetics \\
GKS3 & $18^{\text {th }}$ July 1996 & $32.25 \mathrm{~cm}$ & $0.25 \mathrm{~cm}$ & WW, DW, LOI, CHN, pigments \\
GKS5 & $18^{\text {th }}$ July 1996 & $49.75 \mathrm{~cm}$ & $0.25 \mathrm{~cm}$ & WW, DW, LOI, metals \\
\hline
\end{tabular}

2000). Dates were extrapolated assuming constant sedimentation rates.

\subsection{Mineral magnetics}

Room temperature magnetic measurements were made on freeze-dried $0.25 \mathrm{~cm}$ contiguous samples in the depth range $0-30 \mathrm{~cm}$ in plastic film using a vibrating sample magnetometer, pulse magnetisers and spinner magnetometer. This procedure provided continuous measurements of magnetisation in DC fields $0-1 \mathrm{~T}$ and remanence measurements following fields of $1 \mathrm{~T},-20$ $\mathrm{mT} .,-100 \mathrm{mT}$ and $-300 \mathrm{mT}$ with calculation (cf. Thompson \& Oldfield 1986; Dearing et al. 1998; Walden et al. 1999) of the following mass specific or ratio mineral magnetic parameters and ratios:

- Mass specific susceptibility $\left(\chi_{\text {low }}\right)$

- Mass specific and per cent ferrimagnetic susceptibility $\left(\chi_{\text {ferri }} ; \chi_{\text {ferri }} \%\right)$

- Mass specific and per cent paramagnetic susceptibility $\left(\chi_{\text {para }} ; \chi_{\text {para }} \%\right)$

- Mass specific saturation magnetisation $\left(M_{s}\right)$

- Ratio saturation remanence: susceptibility $\left(\mathrm{M}_{\mathrm{rs}} / \chi_{\text {low }}\right)$

- Ratio saturation remanence: saturation magnetisation $\left(\mathrm{M}_{\mathrm{rs}} / \mathrm{M}_{\mathrm{s}}\right)$

- Mass specific saturation remanent magnetisation (SIRM)

- Mass specific and per cent soft (-20 mT) remanence (soft IRM; soft IRM \%)

- Mass specific and per cent medium (-100 - -20 mT) remanence $\left(\mathrm{IRM}_{100-20} \mathrm{mT} ; \mathrm{IRM}_{100-20} \mathrm{mT} \%\right)$

- Mass specific and per cent hard (-300 mT) remanence (HIRM; HIRM\%)

\subsection{Iron and manganese}

Total iron was measured as $\mathrm{Fe}_{2} \mathrm{O}_{3}$, total manganese was analysed as $\mathrm{MnO}$, using WDXRFA (wavelength dispersive X-ray analysis) with powder pellet technique.

\subsection{Carbon and nitrogen}

Carbon and nitrogen were measured on a dried and weighed sub-sample using a $\mathrm{CHN}$ analyser (Carlo Erba, model 1106).

\subsection{Pigments}

Pigment analyses were performed on weighed subsamples of $c a 0.5 \mathrm{~g}$ wet weight. Pigments were extracted overnight with $90 \%$ acetone, according to Lami et al. (1994) and Lami et al. (2000). The suspension was centrifuged at $4000 \mathrm{rpm}$ for 10 minutes. The supernatant was analysed for total pigments (chlorophylls and their derivatives, CD; total carotenoids, TC) with a spectrophotometer. An aliquot of the same acetone extract was injected in an HPLC system for measuring single specific carotenoids. Chlorophyll derivatives were expressed as spectrophotometric units per gram organic matter $\left(\mathrm{U} \mathrm{gOM}^{-1}\right)$ (Guilizzoni et al. 1983). The total and the single carotenoids were expressed as $\mathrm{mg} \mathrm{gOM}^{-1}$ and nmoles $\mathrm{gLOI}^{-1}$, respectively (Züllig 1985; Lami et al. 2000).

\subsection{Diatoms \& Chrysophytes}

Samples were cleaned following standard methods, described by Battarbee (1986). After cleaning, the samples were split for diatom and chrysophyte analyses.

Diatom samples were embedded in Naphrax and counted in phase contrast and bright field, using Leitz Laborlux S microscope with Plan Apo 100, 1.32 Oel and Plan Apo 63, 1.40 Oel. A minimum of 120 valves were counted in continuous samples and of 500 valves in non continuous samples ( $1 \mathrm{~cm}$ interval). Taxonomy followed Krammer \& Lange-Bertalot (1986-1991) and Wunsam et al. (1995).

For chrysophyte analysis, a minimum of 200 cysts per sample were counted in SEM (Jeol JSM-35), following the procedure described in Kamenik et al. (2000).

\subsection{Numerical analyses}

Biostratigraphical zones were detected by Constrained Incremental Sum of Squares cluster analysis (CONISS, Grimm 1987). Changes in the diatom and chrysophyte assemblage compositions were illustrated by Detrended Correspondence Analysis (DCA; detrending by segments). DCA is the preferred method, because the sample scores are scaled as 'standard deviation units' of compositional change (Birks 1998). The influence of environmental factors that may have caused changes in the species composition were traced with Principal Components Analysis (PCA, ter Braak 1995).

Diatom and chrysophyte stomatocyst data were square root transformed for all analyses. All available transformations were applied to pigment data in CONISS, and only consistent zone boundaries were selected. The statistical significance of zone boundaries 
and ordination axes was tested by the broken stick model (Jollifer 1986; Grimm 1987; Jackson 1993).

\section{RESULTS}

\subsection{Chronology}

In GKS2, equilibrium of total ${ }^{210} \mathrm{~Pb}$ activity with the supporting ${ }^{226} \mathrm{Ra}$, corresponding to $c a 150$ years accumulation, was reached at a depth of about $9 \mathrm{~cm} .{ }^{226} \mathrm{Ra}$ activity was relatively constant throughout the core, with a mean value of $58 \mathrm{~Bq} \mathrm{~kg}^{-1}$. Unsupported ${ }^{210} \mathrm{~Pb}$ activity reached its maximum value at a depth of 2.5-2.75 $\mathrm{cm}$ below the sediment surface, though there was little significant reduction throughout the top $4.25 \mathrm{~cm}$. Below $4.5 \mathrm{~cm}$, unsupported ${ }^{210} \mathrm{~Pb}$ concentrations declined more or less exponentially with depth, suggesting relatively uniform sedimentation rates in the older sediments.

The ${ }^{137}$ Cs activity versus depth profile had a well-resolved peak at $2.0-2.75 \mathrm{~cm}$. A small peak in ${ }^{214} \mathrm{Am}$ activity at $3.5-4.25 \mathrm{~cm}$, coupled with a small shoulder on the ${ }^{137} \mathrm{Cs}$ profile at the same depth, identifies these sediments as dating from ca1963, the year of maximum fallout from the atmospheric testing of nuclear weapons. Thus the ${ }^{137} \mathrm{Cs}$ peak at $2.0-2.75 \mathrm{~cm}$ almost certainly rec??ords fallout from the 1986 Chernobyl accident.

The results of the CRS dating model, given in figure $2 \mathrm{~A}$, put 1986 at a depth of $2.25-2.5 \mathrm{~cm}$, and 1963 at a depth of 3.75-4.0 cm, in excellent agreement with the ${ }^{137} \mathrm{Cs}$ and ${ }^{241} \mathrm{Am}$ dates. Below $4.5 \mathrm{~cm}$, dated 1951, sedimentation rates appear to have been slow but very uniform for more than a century. The mean value for this period is calculated to be $0.0022 \pm 0.0002 \mathrm{~g} \mathrm{~cm}^{-2} \mathrm{y}^{-1}$ $\left(0.036 \mathrm{~cm} \mathrm{y}^{-1}\right)$. Since then sedimentation rates have increased to present day values of $0.013 \mathrm{~g} \mathrm{~cm}^{-2} \mathrm{y}^{-1}$. Extrapolated dates (below $8.5 \mathrm{~cm}$ ) have been calculated using the uniform sedimentation rate of $0.0022 \pm 0.0002$ $\mathrm{g} \mathrm{cm}^{-2} \mathrm{y}^{-1}$.

Estimated and extrapolated dates for GKS3, GKS5 and GKS95 are given in figure 2B. Dates were extrapolated assuming a constant sedimentation rate of 0.034 $\mathrm{cm} \mathrm{y}^{-1}, 0.036 \mathrm{~cm} \mathrm{y}^{-1}$ and $0.041 \mathrm{~cm} \mathrm{y}^{-1}$, respectively. Details on core correlation and chronology are described in Koinig et al. (2000).

\subsection{Sedimentology and Geochemistry}

\subsubsection{Mineral Magnetics}

The sediments of Gossenköllesee are magnetically weak. The most pronounced changes among the magnetic parameters could be found in SIRM and SOFT\%. These parameters, showing increasing concentrations and proportions of stable single domain 'magnetite' or 'hematite' upcore, separated the core into two sections: a rather stable section below $10 \mathrm{~cm}$ and a section of increasing SIRM and decreasing SOFT\% above $10 \mathrm{~cm}$ (Fig. 3).

Core section $17-14 \mathrm{~cm}$ as well as $2-0 \mathrm{~cm}$ were characterised by an increase in $\chi_{\text {para }}$. Highest values of $\chi_{\text {para }}$ and HIRM were found from 7 to $6 \mathrm{~cm}$. An increase in HIRM was detected between 13 and $7 \mathrm{~cm}$ (Fig. 3).

A GKS2 core

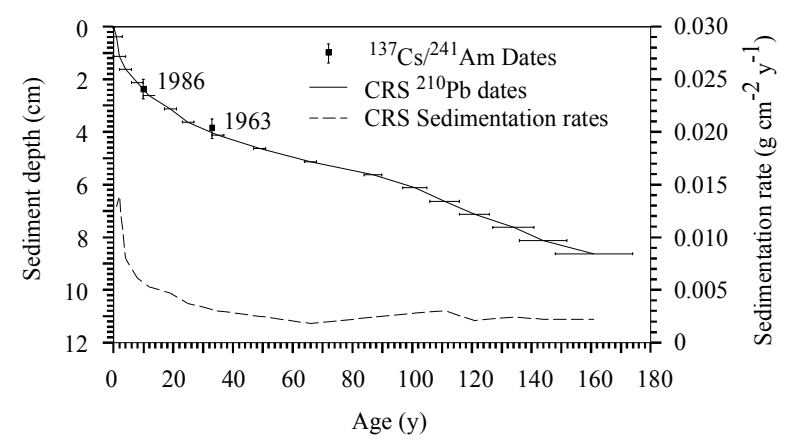

B

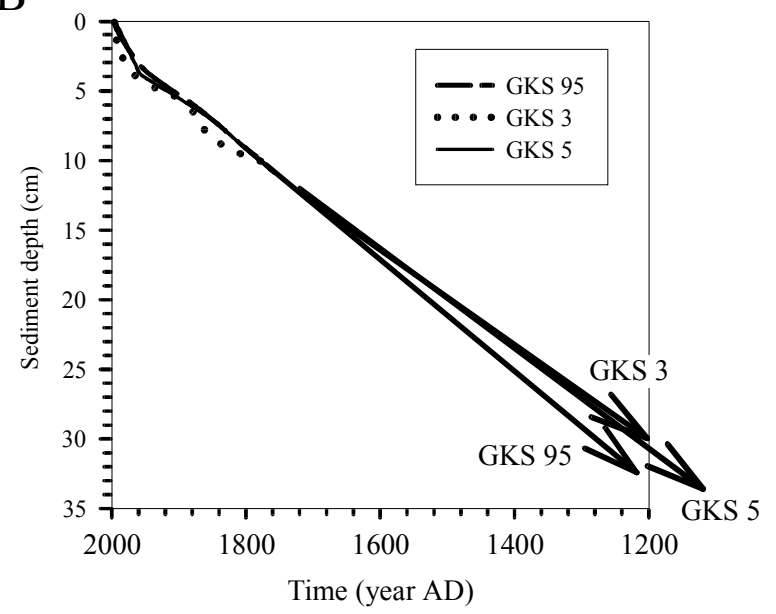

Fig. 2. A: Radiometric chronology of Gossenköllesee core GKS2 showing CRS model ${ }^{210} \mathrm{~Pb}$ dates together with dates determined from the ${ }^{137} \mathrm{Cs}$ and ${ }^{241} \mathrm{Am}$ stratigraphy. Also shown are sedimentation rates calculated using the CRS model. B: Estimated dates, obtained from sequence slotting (GKS3, GKS5) and from applying an average accumulation rate (GKS95), and extrapolated dates, assuming a constant sedimentation rate (arrows).

\subsubsection{Iron and Manganese}

Iron and manganese showed a similar trend (Fig. 3). In the lower core section $(>12.7 \mathrm{~cm})$ values for iron and manganese were very close to or below detection limit. The highest values of iron and manganese were found between $7.0-8.8 \mathrm{~cm}$. There were no marked changes in the $\mathrm{Fe} / \mathrm{Mn}$ ratio.

\subsubsection{Carbon and Nitrogen}

Total carbon varied between $10-25 \% \mathrm{DW}$, and total nitrogen between 1.5-4.0\% DW. Both were well correlated throughout the core $(\mathrm{R}=0.84, \mathrm{P}<0.01)$. The most pronounced changes were found between $22 \mathrm{~cm}$ and 19 $\mathrm{cm}$, where carbon and nitrogen declined dramatically from the highest to the lowest concentrations (Fig. 3).

The $\mathrm{C} / \mathrm{N}$ ratio varied between $c a 6$ and 10, illustrating mainly autochthonous production of organic matter. 


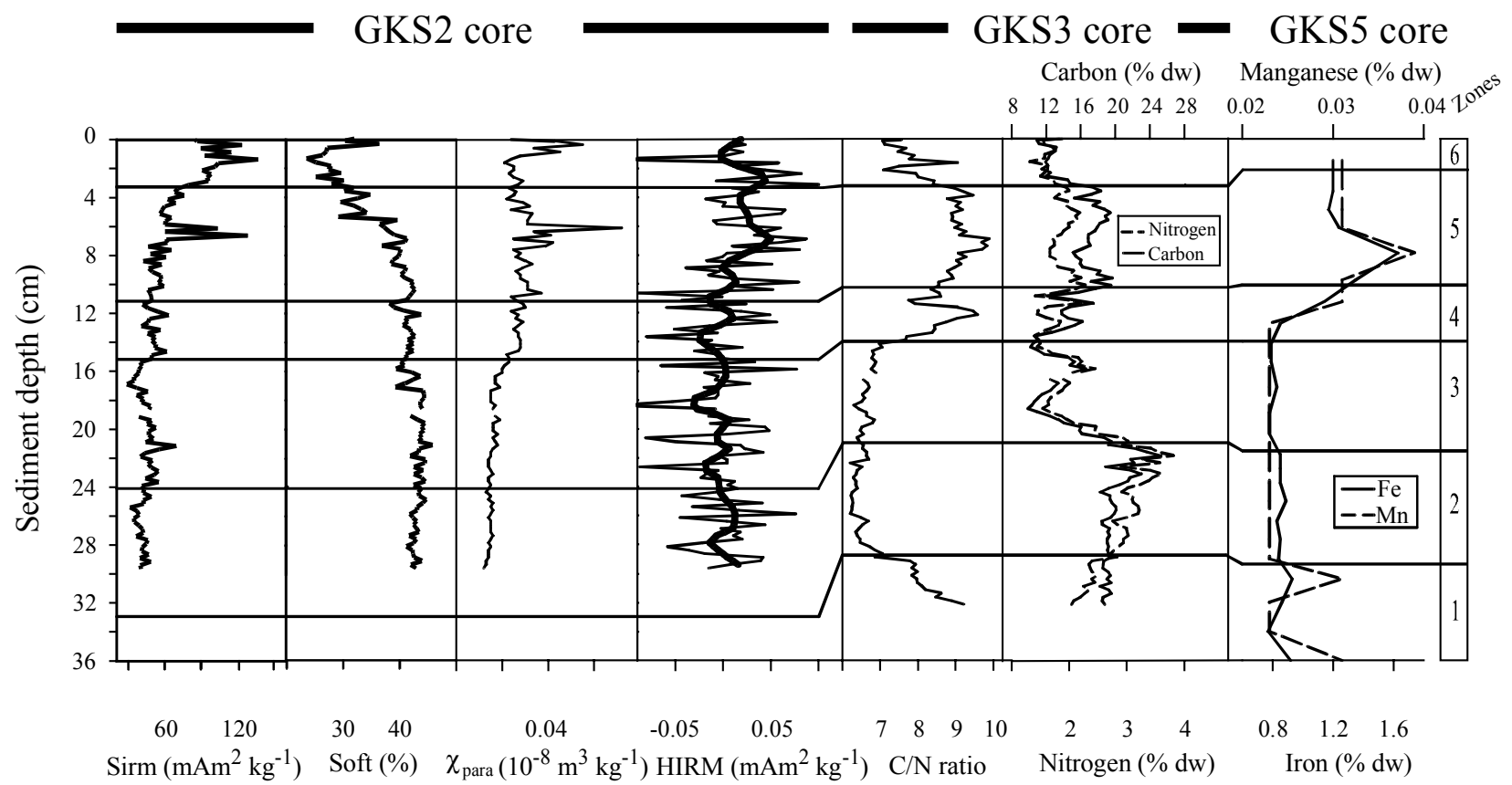

Fig. 3. Profiles of SIRM, SOFT\%, $\chi_{\text {para }}$, HIRM, carbon, nitrogen, $\mathrm{C} / \mathrm{N}$ ratio, iron and manganese. Zone boundaries were set according to a combined interpretation of all results.

Lowest values were found between $28 \mathrm{~cm}$ and $14 \mathrm{~cm}$ (Fig. 3). A high correlation between carbon and loss-onignition $(\mathrm{R}=0.93, \mathrm{P}<0.01)$ indicates organic carbon as major component.

\subsection{Bioindicators}

\subsubsection{Pigments}

The presence of labile chlorophylls and carotenoids (e.g. peridinin, fucoxanthin) and the independent measurement of the index $430 \mathrm{~nm}: 410 \mathrm{~nm}$ (Guilizzoni et al. 1992; Lami et al. 2000, this issue) revealed good pigment preservation throughout the core. In most parts of the core concentrations of chlorophylls and some carotenoids (e.g. $\beta$-carotene, lutein) were similar to those found in moderately productive lakes, although phaeopigment concentrations were always higher.

In agreement with CONISS results the pigment profile was split into 4 zones (Fig. 4 - the zone boundary at $14 \mathrm{~cm}$ was set as a result of changes in the $\mathrm{C} / \mathrm{N}$ ratio, in $\chi_{\text {para }}$ and in iron and manganese concentrations; the zone boundary at $3.1 \mathrm{~cm}$ was set because of changes in the $\mathrm{C} / \mathrm{N}$ ratio).

In zone 1 there are high concentrations of almost all pigments. The zone boundary at $28.8 \mathrm{~cm}$ is characterised by a sharp decline in $\beta$-carotene, alloxanthin, lutein and echinenon. Zone 2 generally shows slightly higher pigment concentrations than zones 3 and 4 . The zone boundary at $21.2 \mathrm{~cm}$ is set by a marked decrease of lutein, chlorophyll- $b$, astaxanthin and rhodopinal, which reached high values towards the top of zone 2. Zone 5 is characterised by lowest pigment concentrations. Since high concentrations of pigments in the uppermost layers of zone 6 might have been caused by different pigment preservation, as shown by the higher concentration of labile pigments (e.g. chlorophyll- $a$, chlorophyll- $b$, chlorophyll-c, dinoxanthin, fucoxanthin, oscillaxanthin, myxoxanthophyll and peridinin), no zone boundary was established.

\subsubsection{Diatoms}

A total of 67 different diatom species were found in Gossenköllesee. Fifty-seven of these taxa reached species abundance $>1 \%$ in at least one sample and were used for further statistical analysis. The diatom stratigraphy is shown in figure 5 . Because the broken stick model did not indicate significant zone boundaries for diatom assemblages, zones in figure 5 were set according to pigment, $\mathrm{C} / \mathrm{N}, \chi_{\text {para }}$, iron and manganese data. Dominant diatom taxa (of the genera Cyclotella and Fragilaria) did not show clear trends in the zones 2, 3, 5, 6 (zone 1 was not included in the core). In zone $4 C y$ clotella gordonensis and Fragilaria brevistriata showed a clear increase and Fragilaria X- large lapponica (an unknown Fragilaria) showed a clear decrease from the bottom to the top of the zone. Fragilaria oldenburgiana first appeared in zone 4.

The first two DCA axes explain $18.8 \%$ of the variance in the diatom percentage data (Fig. 6). The two axes divide the core into two zones with the boundary at $10.5 \mathrm{~cm}$ (in agreement with the boundary of zone 4 to zone 5). As a result of the short gradient lengths of the significant DCA axes $(<1.2$ standard deviations), PCA 

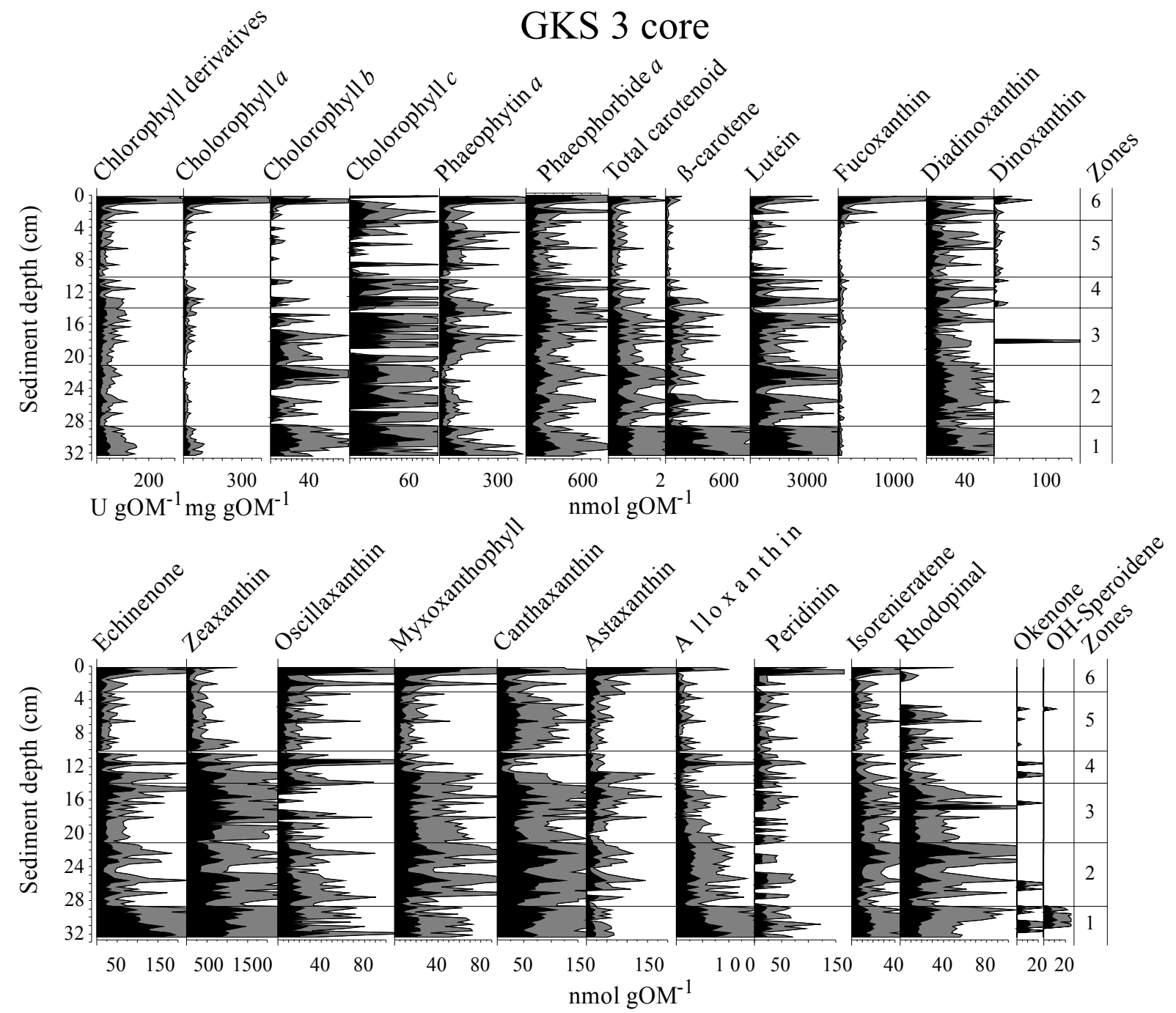

Fig. 4. Pigment stratigraphy: non-specific pigments (chlorophyll derivatives, total carotenoids, $\beta$-carotene chlorophyll- $a$ and phaeophytin-a), cryptophyta (alloxanthin), chlorophytes (lutein, chlorophyll-b), chrysophyta (fucoxanthin, diadinoxanthin, chlorophyll-c, dinoxanthin), cyanobacteria (echinenone, zeaxanthin, oscillaxanthin, myxoxanthophyll, astaxanthin), pigments indicating grazing (astaxanthin, phaeophorbides), sulphur bacteria (isorenieratene, rhodopinal, okenone, OH-spheroidene) and pyrrophytes (peridinin). Grey areas show data 3 times exaggerated. Zone boundaries were set according to a combined interpretation of all results.

was used to detect the diatom species causing the separation of the two core sequences. All four axes are significant, explaining $34 \%$ of the total variance. The following taxa are correlated mainly with PCA axis 2 which separates the lower core section from the upper one: Cyclotella gordonensis, Nitzschea pura and Achnanthes minutissima, with higher numbers in the upper core section; and Fragilaria X-large lapponica, Fragilaria robusta, Fragilaria elliptica, Fragilaria construens subsalina, and Fragilaria pseudoconstruens, prevailing in the lower core section.

\subsubsection{Chrysophytes}

Thirty-six stomatocyst types (with a minimum occurrence $>3 \%$ in at least one sample) were found in the sediment core. Fourteen types were described as new, together with the stratigraphic distribution illustrated by Kamenik et al. (2000). DCA indicates one significant axis, explaining $15.4 \%$ of the variance (Fig. 6). CONISS distinguished two zones, with a significant boundary in $10.25 \mathrm{~cm}$.

\section{DISCUSSION}

\subsection{Zone 1 (<ca $1200 A D)$}

In this zone the highest concentrations for most of the pigments were observed, indicating high productivity. High alloxanthin concentrations, originating from cryptophytes, might indicate reduced ice cover (Smol et al. 1991). A decrease of the $\mathrm{C} / \mathrm{N}$ ratio towards the top might have been caused by an increased input of nitrogen. 


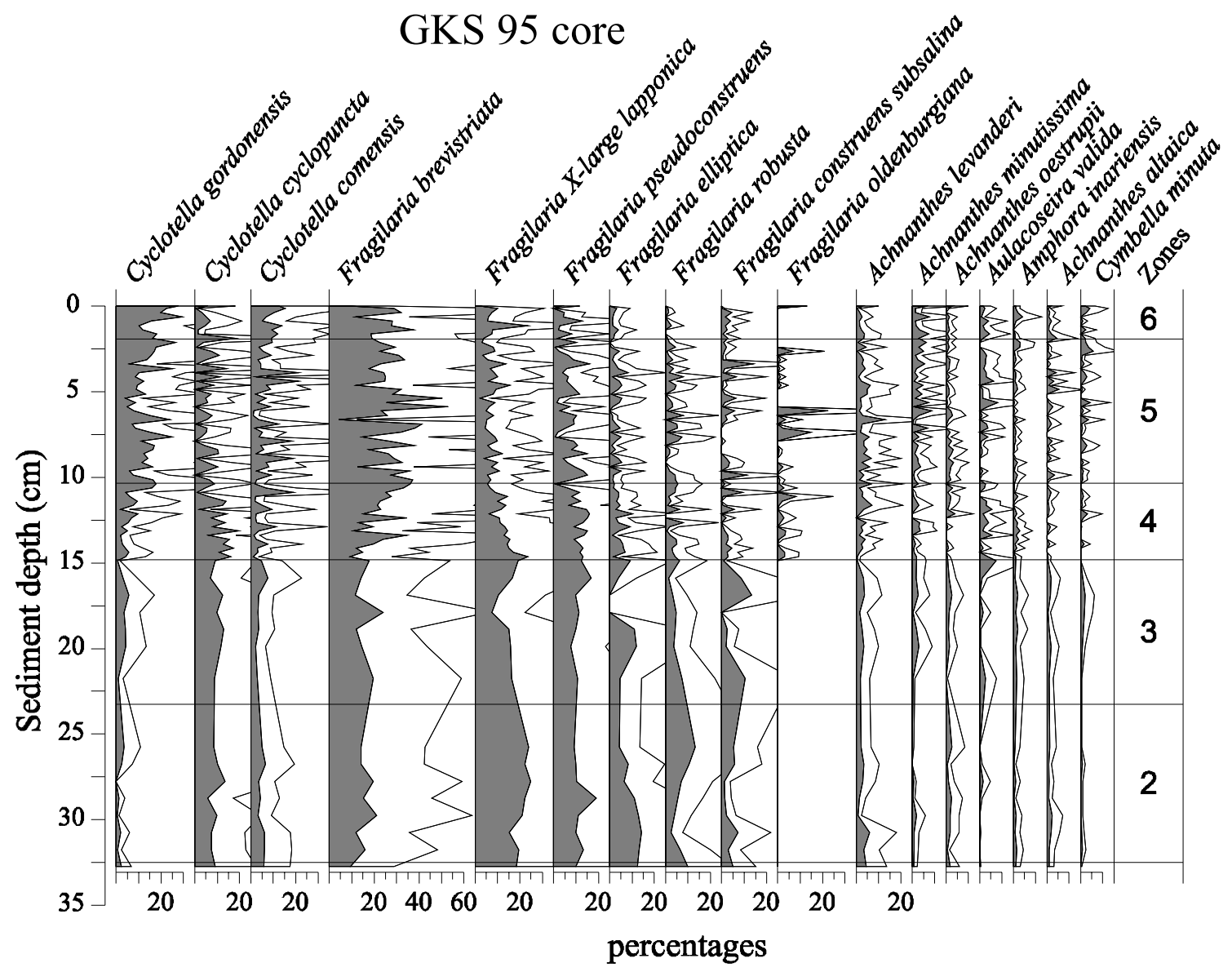

Fig. 5. Diatom stratigraphy (only taxa with mean relative abundance $>2 \%$ are shown). The lines show data 3 times exaggerated. Zone boundaries were set according to a combined interpretation of all results.

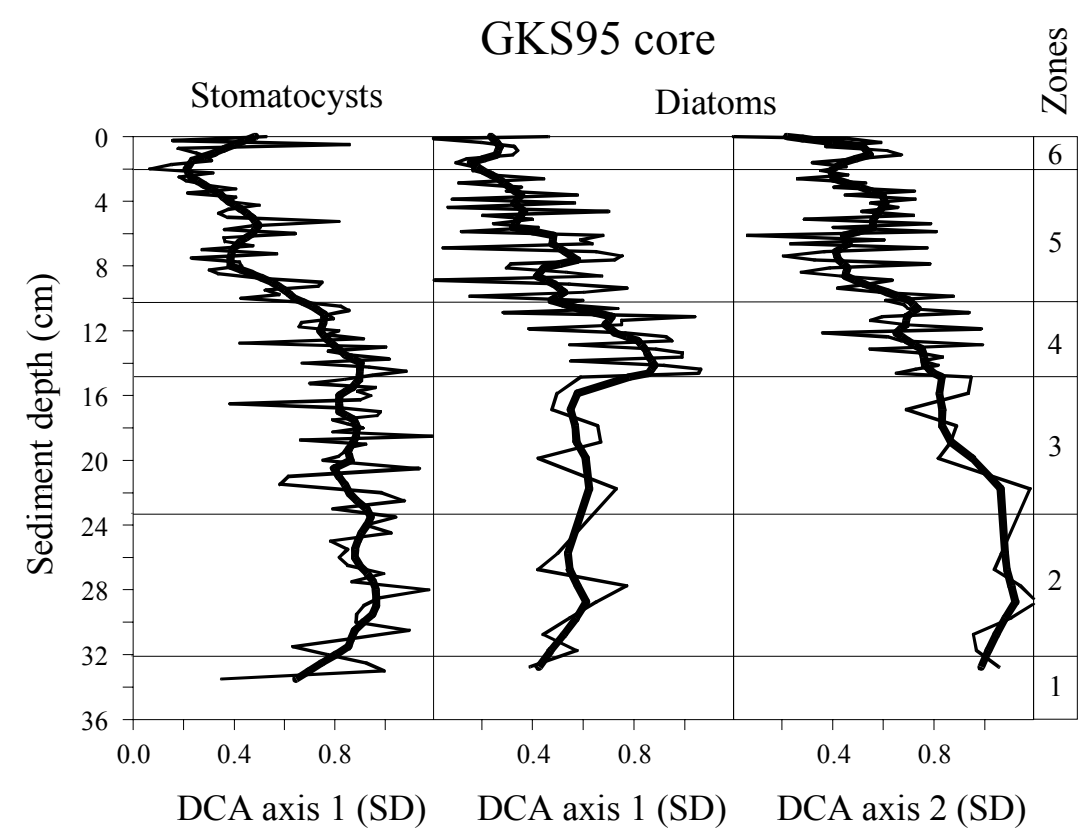

Fig. 6. DCA-scores $v s$ depth profiles indicating changes in chrysophyte stomatocyst and diatom assemblage compositions. Zone boundaries were set according to a combined interpretation of all results. 
Pollen analysis has shown that there has been continuous human influence in Kühtai since Roman times (Hüttemann \& Bortenschlager 1987). Historical archives from 1303 AD (Stolz 1930) report intensive sheep and cattle farming in Kühtai. In Tyrol these socalled "Schwaighöfe" were established during the $12^{\text {th }}$ century, with pastures up to 2500 m a.s.l. (Patzelt 1996; Patzelt et al. 1997). The onset of glacier retreat during the $10^{\text {th }} / 11^{\text {th }}$ century (Patzelt 1973) supports the hypothesis that there would have been an increase in productivity as a result of both in-lake production and the input of nutrients from pasture at high altitude.

\subsection{Zone 2 (ca 1200 - ca $1450 A D$ )}

Impact of climate and human influence are assumed to overlap in this zone, as in zone 1 : the $\mathrm{C} / \mathrm{N}$ ratio remained low, probably as a result of nitrogen input from pastures (Stolz 1930). Significant nutrient input is indicated by chrysophyte stomatocyst assemblages, described from slightly meso- to eutrophic lakes (Kamenik et al. 2000). Nutrient input, however, was not coupled with catchment erosion. This is indicated by low values of mineral magnetic parameters indicative of detrital paramagnetic and canted antiferromagnetic minerals $\left(\chi_{\text {para }}\right.$, HIRM$)$, iron and manganese.

Pigment concentrations fluctuated in zone 2, starting with a minimum in the lower part and increasing towards the top. Minimum pigment concentrations, dated approx. 1250 - $1270 \mathrm{AD}$, coincide with a pronounced glacier advance (Patzelt 1973). Pigment peaks of green algae (lutein, chlorophyll- $b$ ) correlate with prominent peaks in carbon and nitrogen. Anaerobic photosynthetic bacteria (e.g. rhodopinal, isorenieratene) may have been favoured by organic matter accumulation. This event, dated $1430 \mathrm{AD}$, coincides with glacial retreat, as reconstructed for nearby Hintereisferner (Nicolussi 1994).

\subsection{Zone 3 (ca 1450 - ca $1670 A D$ )}

The main difference from the former zone was assumed to be a change in the food web by fish stocking: Arctic charr (Salmo trutta morpha fario L.) was introduced to Gossenköllesee, most probably at the end of the fifteenth century (Pechlaner 1966). The decrease in alloxanthin (cryptophytes) and canthaxantin (grazers) points to a significant removal of grazers by fish (Leavitt 1993; Vinebrooke \& Leavitt 1999). The decline of carbon and nitrogen illustrates loss of organic material either as a result of the metabolic activity of fish (Elliot 1976) or fishing.

\subsection{Zone 4 (ca 1670 - ca $1770 A D$ )}

Winter temperatures declined in the $1670 \mathrm{~s}$, and from 1688 - $1701 \mathrm{AD}$ a pronounced cold period was observed (Pfister 1985). Since the "Schwaighof" was sold to the Earl of Spaur in $1675 \mathrm{AD}$, farm management around Gossenköllesee probably changed (Stolz 1930).
A peak in the $\mathrm{C} / \mathrm{N}$ ratio, an increase in iron and manganese and slightly higher $\chi_{\text {para }}$ indicates input of material from the catchment.

\subsection{Zone 5 (ca 1770 - ca $1975 A D$ )}

The trend of increased catchment erosion, starting in zone 4 , culminated in zone 5 . Peaks in $\mathrm{C} / \mathrm{N}$ ratio, iron and manganese concentrations, $\chi_{\text {para }}$ and HIRM indicate high levels of allochthonous material around 1870 AD. Peaks occur at slightly different times, possibly due to different sediment sources (Dearing 1999), or dating inaccuracy from sequence slotting. Erosion is also illustrated by an increase in zirconium concentrations (Koinig unpublished). The comparatively small increase in the $\mathrm{C} / \mathrm{N}$ ratio (Kaushal \& Binford 1999) may be caused by the low area/volume of soil in the catchment (ca 10\% of the catchment area; Heisberger 1988).

Pigment concentrations were at a minimum, indicating low productivity. This finding is supported by a significant change in the chrysophyte stomatocyst assemblage composition to types observed under oligotrophic conditions (Kamenik et al. 2000). The "Schwaighof" near Gossenköllesee was abandoned no later than $1890 \mathrm{AD}$ (Stolz 1930).

In sum these environmental changes might have been affected by a less favourable climate ("Little Ice Age": marked advance of alpine glaciers 1820 - 1850 AD; Patzelt 1973) and re-oligotrophication by a less intensive use of alpine pastures (Stolz 1930, Paldele 1994).

\subsection{Zone 6 (ca 1975 - present day)}

An increase in pigment concentration towards the sediment surface may indicate an increase in in-lake productivity, as a result of recent climate warming (Beniston et al. 1997), even if it might also be due to the presence of non degraded pigments, as evidenced by the high concentrations of labile pigments and of the ratio 430:410 nm Guilizzoni et al. 1992; Leavitt 1993). A decrease in the $\mathrm{C} / \mathrm{N}$ ratio suggests an increase in autochthonous production.

The increase of $\chi_{\text {para }}$ indicates that erosion processes were further enhanced after $c a$ 1993. The increase of SIRM may indicate an influx of minerogenic material containing 'hematite' but alternatively may be caused by magnetotactic bacteria that produced single domain 'magnetite'.

\section{CONCLUSIONS}

The history of Gossenköllesee during the last 800 years reveals complex interactions between anthropogenic impacts and climate. Alpine pastures, which were intensively used during medieval time, supplied nutrients, which raised in-lake production. Fish stocking, which started at the end of the $15^{\text {th }}$ century, has influenced the food web. During phases of temperature de- 
cline, in-lake production was reduced and erosion increased. These processes reach a culmination during the period of glacier advances in $1820-1850 \mathrm{AD}$. Because a similar trend was not observed during cold periods prior to $c a 1670 \mathrm{AD}$, it appears that in-lake production during these times was more influenced by changes in land-use than by climatic factors.

\section{ACKNOWLEDGMENTS}

We would like to thank Stefan Andreatta, Sabine Sommaruga-Wögrath, Ruben Sommaruga, Gitte Vacha and Anton Wille (University of Innsbruck), Hannes Höllerer and Johann Knoll (Institute of Limnology, Mondsee) for help in the field. We are grateful to $\mathrm{Ru}$ Yuchan $\mathrm{Hu}$ (University of Liverpool) for making the magnetic measurements and to Richard Tessadri (University of Innsbruck) for analysing iron and manganese. This study was supported by the European Commission, Environment and Climate Programme MOLAR (Mountain Lake Research, project number: ENV4-CT0007).

\section{REFERENCES}

Appleby, P.G. 1993. Forward to the ${ }^{210} \mathrm{~Pb}$ dating anniversary series. J. Paleolimnol., 9: 155-160.

Appleby, P.G. 1998. Dating recent sediments by ${ }^{210} \mathrm{~Pb}$ : Problems and solutions. $2^{\text {nd }}$ NKS/EKO-1 Seminar, Helsinki, Finland; 2-4 April 1997.

Appleby, P.G., P.J. Nolan, D.W. Gifford, M.J. Godfrey, F. Oldfield, N.J. Anderson \& R.W. Battarbee. $1986 .{ }^{210} \mathrm{~Pb}$ dating by low background gamma counting. Hydrobiologia, 141: 21-27.

Appleby, P.G. \& F. Oldfield. 1978. The calculation of ${ }^{210} \mathrm{~Pb}$ dates assuming a constant rate of supply of unsupported ${ }^{210} \mathrm{~Pb}$ to the sediment. Catena, $5: 1-8$.

Appleby, P.G. \& F. Oldfield. 1983. The assessment of ${ }^{210} \mathrm{~Pb}$ data from sites with varying sediment accumulation rates. Hydrobiologia, 103: 29-35.

Appleby, P.G., N. Richardson \& P.J. Nolan. 1991. ${ }^{241}$ Am dating of lake sediments. Hydrobiologia, 214: 35-42.

Appleby, P.G., N. Richardson \& P.J. Nolan. 1992. Self-absorption corrections for well-type germanium detectors. Nucl. Instrum. Meth. B, 71: 228-233.

Battarbee, R.W. 1986. Diatom analysis. In: Berglund, B.E. (Ed.), Handbook of Holocene Palaeoecology and Palaeohydrology. John Wiley and Sons, Chichester: 527-570.

Beniston, M., H.F. Diaz \& R.S. Bradley. 1997. Climatic change at high elevation sites: An overview. In: Diaz, H.F., M. Beniston \& R.S. Bradley (Eds), Climatic change at high elevation sites. Kluwer Academic Publishers, Dordrecht: 1-19.

Birks, H.J.B. 1998. Numerical tools in palaeolimnology - Progress, potentials, and problems. J. Paleolimnol., 20: 307 332

Dearing, J.A. 1999. Holocene environmental change from magnetic proxies in lake sediments. In: Maher, B.A. \& R Thompson (Eds), Quaternary Climates, Environments and Magnetism. Cambridge University Press, Cambridge: 231278

Dearing, J.A., J.F. Boyle, P.G. Appleby \& A.W.F.R.J. Mackay. 1998. Magnetic properties of recent sediments in Lake Baikal, Siberia. J. Paleolimnol., 20: 163-173.

Elliot, J.M. 1976. The energetics of feeding, metabolism and growth of brown trout (Salmo trutta L.) in relation to body weight, water temperature and ration size. J. Anim. Ecol., 45: 923-948.

Grabherr, G., M. Gottfried \& H. Pauli. 1994. Climate effects on mountain plants. Nature, 369: 448.

Grimm, E.C. 1987. CONISS: a FORTRAN 77 program for stratigraphically constrained cluster analysis by the methods of incremental sum of squares. Comput. Geosci., 13: 13-35.

Guilizzoni, P., G. Bonomi, G. Galanti \& D. Ruggiu. 1983. Relationship between sedimentary pigments and primary production: evidence from core analyses of twelve Italian lakes. Hydrobiologia, 103: 103-106.

Guilizzoni, P., A. Lami \& A. Marchetto. 1992. Plant pigment ratios from lake sediments as indicators of recent acidification in alpine lakes. Limnol. Oceanogr., 37: 1565-1569.

Heisberger, F. 1988. Die Böden im Einzugsgebiet des Gossenköllesees und des Mutterbergersees. In: Psenner, R., K. Arzet, A. Brugger, J. Franzoi, F. Heisberger, W. Honsig-Erlenburg, F. Horner, W. Müller, U. Nickus, P. Pfister, P. Schaber \& F. Zapf, Versauerung von Hochgebirgsseen in kristallinen Einzugsgebieten Tirols und Kärntens. Zustand, Ursachen, Auswirkungen, Entwicklungen. Bundesministerium für Land- und Forstwirtschaft, Wien: 259-322.

Hüttemann, H. \& S. Bortenschlager. 1987. Beiträge zur Vegetationsgeschichte Tirols VI: Riesengebirge, Hohe Tatra - Zillertal, Kühtai. Ber. Nat.-Med. Verein Innsbruck, 74: $81-112$

Jackson, D.A. 1993. Stopping rules in principal components analysis: a comparison of heuristical and statistical approaches. Ecology, 74: 2204-2214.

Jollifer, I.T. 1986. Principal components analysis. SpringerVerlag, New York: $271 \mathrm{pp}$.

Kamenik, C., R. Schmidt, K.A. Koinig, A. Agustí-Panareda, R. Thompson \& R. Psenner. (2000). The Chrysophyte stomatocyst composition in a high alpine lake (Gossenköllesee, Tyrol) in relation to seasonality, temperature and land-use. Beih. Nova Hedwigia: in press.

Kaushal, S. \& M.W. Binford. 1999. Relationship between C:N ratios of lake sediments, organic matter sources, and historical deforestation in Lake Pleasant, Massachusetts, USA. J. Paleolimnol., 22: 439-442.

Koinig, K.A., C. Kamenik, R. Schmidt, A. Agustí-Panareda, P. Appleby, J. Fott, A. Lami, N. Rose, Ø.A. Schnell, R. Tessadri, R. Thompson \& R. Psenner. (2000). Palaeoenvironmental changes in an alpine lake (Gossenköllesee, Austria) over the last 200 years - the influence of air temperature on biological parameters. J. Paleolimnol.: submitted.

Koinig, K.A., S. Sommaruga-Wögrath, R. Schmidt, R. Tessadri \& R. Psenner. 1998. Acidification processes in high alpine lakes - Impacts of atmospheric deposition and global change. In: Haigh, M.J., J. Krecek, G.S. Rajwar \& M.P. Kilmartin, Headwaters: Water Resources and Soil Conservation. Proceedings of Headwater '98: 45-54.

Krammer, K. \& H. Lange-Bertalot. 1986-1991. Bacillariophyceae. In: Ettl, H., J. Gerloff, H. Heying \& D. Mollenhauer (Eds), Süßwasserflora von Mitteleuropa. Gustav Fischer Verlag, Stuttgart.

Lami, A., P. Guilizzoni \& A. Marchetto. 2000. High resolution analysis of fossil pigments, carbon, nitrogen and sulphur in the sediment of eight European alpine lakes: the MOLAR project. In: A. Lami, N. Cameron \& A. Korhola (Eds), Paleolimnology and ecosystem dynamics at remote European Alpine lakes. J. Limnol., 59 (Suppl. 1): $15-28$.

Lami, A., F. Niessen, P. Guilizzoni, J. Masaferro \& C.A. Belis. 1994. Palaeolimnological studies of the eutrophication of volcanic Lake Albano (Central Italy). J. Paleolimnol., 10: 181-197. 
Leavitt, P.R. 1993. A review of factors that regulate carotenoid and chlorophyll deposition and fossil pigment abundance. J. Paleolimnol., 9: 109-127.

Nicolussi, K. 1994. Jahresringe und Massenbilanzen - Dendroklimatologische Rekonstruktion der Massenbilanzreihe des Hintereisferners bis zum Jahr 1400 mittels Pinus cembra-Reihen aus den Ötztaler Alpen, Tirol. Z. Gletscherk. Glaziol., 30: 11-52.

Paldele, B. 1994. Die aufgelassenen Almen Tirols. Innsbrucker Geographische Studien, Innsbruck: $160 \mathrm{pp}$.

Patzelt, G. 1973. Die neuzeitlichen Gletscherschwankungen in der Venedigergruppe (Hohe Tauern, Ostalpen). $Z$. Gletscherk. Glaziol., 9: 5-57.

Patzelt, G. 1996. Modellstudie Ötztal - Landschaftsgeschichte im Hochgebirgsraum. Mitt. D. Österr. Geogr. Ges., 138: 53-70.

Patzelt, G., W. Kofler \& B. Wahlmüller. 1997. Entwicklung der Landnutzung im Ötztal. Jahresbericht 1997. Institut für Hochgebirgsforschung, Innsbruck: 26-33.

Pechlaner, R. 1966. Salmonideneinsätze in Hochgebirgsseen und -tümpeln der Ostalpen. Verh. int. Ver. Limnol., 16: 1182-1191.

Pfister, C. 1985. Klimageschichte der Schweiz 1525 - 1860. Verlag Paul Haupt, Bern: 184 pp.

Psenner, R. \& R. Schmidt. 1992. Climate-driven $\mathrm{pH}$ control of remote alpine lakes and effects of acid deposition. Nature, 356: 781-783.

Schmidt, R. \& R. Psenner. 1992. Climate changes and anthropogenic impacts as causes for $\mathrm{pH}$ fluctuations in remote high alpine lakes. Documenta Ist. ital. Idrobiol., 32: 31-57.

Smol, J.P., I.R. Walker \& P.R. Leavitt. 1991. Paleolimnology and hindcasting climatic trends. Verh. int. Ver. Limnol., 24: $1240-1246$.

Sommaruga-Wögrath, S., K.A. Koinig, R. Schmidt, R. Sommaruga, R. Tessadri \& R. Psenner. 1997. Temperature effects on the acidity of remote alpine lakes. Nature, 387: 64-67.

Stolz, O. 1930. Die Schwaighöfe in Tirol - Ein Beitrag zur Siedlungs- und Wirtschaftsgeschichte der Hochalpentäler. Wiss. Veröff. D. Dt. U. Oe. Alpenvereins, 5: 1-197. ter Braak, C.J.F. 1995. Ordination. In: Jongman, R.H.G., C.J.F. ter Braak \& O.F.R. van Tongeren (Eds), Data analysis in community and landscape ecology. Cambridge University Press, Cambridge: 91-173.

Thies, H., U. Nickus, C. Arnold, R. Schnegg, A. Wille \& R. Psenner. 1999. Biogeochemistry of a High Mountain Lake in the Austrian Alps. Verh. int. Ver. Limnol., 27: 1-4.

Thompson, R. \& R.M. Clark. 1989. Sequence slotting for stratigraphic correlation between cores: theory and practice. J. Paleolimnol., 2: 173-184.

Thompson, R. \& F. Oldfield 1986. Environmental Magnetism. Allen \& Unwin, London: 227 pp.

Vinebrooke, R.D. \& P.R. Leavitt. 1999. Phytobenthos and phytoplankon as potential indicators of climate change in mountain lakes and ponds: a HPLC-based approach. J. $N$. Am. Benthol. Soc., 18: 15-33.

Walden, J., F. Oldfield \& J.P. Smith Environmental Magnetism: a practical guide. Quaternary Research Association, London: 185-196.

Wick, L. \& W. Tinner. 1997. Vegetation changes and timberline fluctuations in the Central Alps as indicators of Holocene climate oscillations. Arctic Alpine Res., 29: 445-458.

Wögrath, S. 1995. Hochgebirgsseen in Tirol: Hairlacher See, Gossenköllesee, Mutterbergersee und Schwarzsee ob Sölden. In: Psenner, R., Gewässerversauerung in Österreich: Entwicklung 1989-1992. Bundesministerium für Land- und Forstwirtschaft, Wien: 39-126.

Wunsam, S., R. Schmidt \& R. Klee. 1995. Cyclotella-taxa (Bacillariophyceae) in lakes of the Alpine region and their relationship to environmental variables. Aquat. Sci., 57: 360-386.

Zaderer, P. 1982. Bestand und Produktion der Chironomiden des Gossenköllesees (2413 m ü.N.N., Kühtai, Tirol). Ph.D. Thesis, University of Innsbruck, Innsbruck, Austria.

Züllig, H. 1985. Pigmente phototropher Bakterien in Seesedimenten und ihre Bedeutung für die Seenforschung. Schweiz. Z. Hydrol., 47: 87-126. 